Review

\title{
Role of tumor microenvironment in tumorigenesis
}

\author{
Maonan Wang1,2, Jingzhou Zhao'2, Lishen Zhang2, Fang Wei2, Yu Lian², Yingfeng Wu2 ${ }^{2}$, Zhaojian Gong2, \\ Shanshan Zhang ${ }^{1}$, Jianda Zhou ${ }^{3}$, Ke Cao 3 , Xiayu Li³ ${ }^{3}$ Wei Xiong1,2,3, Guiyuan Li ${ }^{1,2,3}$, Zhaoyang Zeng ${ }^{1,2,3 凶}$, \\ Can Guo ${ }^{1,2,3 凶}$ \\ 1. Key Laboratory of Carcinogenesis of Ministry of Health, Xiangya Hospital, Central South University, Changsha, Hunan 410078, China; \\ 2. Key Laboratory of Carcinogenesis and Cancer Invasion of Ministry of Education, Cancer Research Institute, Central South University, Changsha, Hunan \\ 410078, China; \\ 3. Hunan Key Laboratory of Nonresolving Inflammation and Cancer, Disease Genome Research Center, The Third Xiangya Hospital, Central South \\ University, Changsha, Hunan 410013, China. \\ $\square$ Corresponding authors: Zhaoyang Zeng, Email: zengzhaoyang@csu.edu.cn; or Can Guo, Email: guocde@csu.edu.cn \\ (C) Ivyspring International Publisher. This is an open access article distributed under the terms of the Creative Commons Attribution (CC BY-NC) license \\ (https://creativecommons.org/licenses/by-nc/4.0/). See http://ivyspring.com/terms for full terms and conditions.
}

Received: 2016.09.20; Accepted: 2016.12.22; Published: 2017.02.25

\begin{abstract}
Tumorigenesis is a complex and dynamic process, consisting of three stages: initiation, progression, and metastasis. Tumors are encircled by extracellular matrix (ECM) and stromal cells, and the physiological state of the tumor microenvironment (TME) is closely connected to every step of tumorigenesis. Evidence suggests that the vital components of the TME are fibroblasts and myofibroblasts, neuroendocrine cells, adipose cells, immune and inflammatory cells, the blood and lymphatic vascular networks, and ECM. This manuscript, based on the current studies of the TME, offers a more comprehensive overview of the primary functions of each component of the TME in cancer initiation, progression, and invasion. The manuscript also includes primary therapeutic targeting markers for each player, which may be helpful in treating tumors.
\end{abstract}

Key words: cancer-associated fibroblasts (CAFs), neuroendocrine cells, adipose cells, immune-inflammatory cells, angiogenesis

\section{Introduction}

Currently, ten major characteristics of cancer have been universally recognized, including unlimited multiplication, evasion from growth suppressors, promoting invasion and metastasis, resisting apoptosis, stimulating angiogenesis, maintaining proliferative signaling, elimination of cell energy limitation, evading immune destruction, genome instability and mutation, and tumor enhanced inflammation (Figure 1) [1]. Although researchers now have an understanding of most characteristics of cancer [2-30], the characteristics regarding cancer formation, which is the focus of the current study, remains unknown. After the 'ecological therapy' strategy was widely employed [31], much effort has been devoted to determining how cellular and noncellular components of the tumoral niche help tumors to acquire these characters. These cellular and noncellular components of the tumoral niche comprise tumor the microenvironment (TME). The TME consists of extracellular matrix (ECM) as well as myofibroblasts and cellular players, such as fibroblasts, neuroendocrine (NE) cells, adipose cells, immune-inflammatory cells, and the blood and lymphatic vascular networks [32]. Furthermore, TME has increasingly been shown to dictate aberrant tissue function and play a critical role in the subsequent evolution of more stubborn and advanced malignancies [33]. Oncologists have also found that when the microenvironment in a healthy state, it can help protect against tumorigenesis and invasion. By contrast, if it is not in a healthy state, it will become an accomplice.

The intent of this paper was to summarize the existent knowledge on the potential role of each TME 
component in tumorigenesis: initiation, progression, and metastasis, respectively. We have also summarized some of the main cellular players, such as cancer-associated fibroblasts, immune and inflammatory cells, blood and lymphatic vascular networks, adipose cells, neuroendocrine cells and ECM in the TME, as well as their corresponding targets in TME, in the hope of providing some clues for future TME research. We have also introduced the therapeutic target markers for various parts of TME based on the current research results.

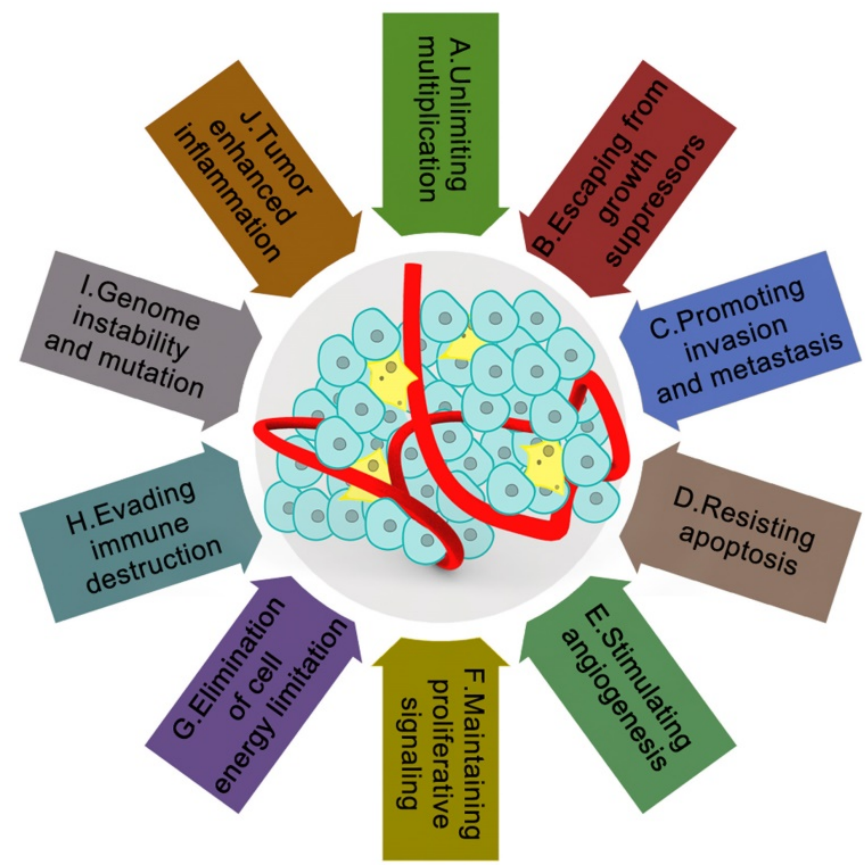

Figure 1. The tumor microenvironment and characteristics of cancer. It is currently widely recognized that tumor microenvironments are wildly influenced by the ten main characteristics of cancer: $A$. unlimited multiplication; B. escaping from growth suppressors; $\mathrm{C}$. promoting invasion and metastasis; D. resisting apoptosis; E. stimulating angiogenesis; F. maintaining proliferative signaling; G. elimination of cell energy limitation; $H$. evading immune destruction; I. genome instability and mutation; J. tumor-enhanced inflammation. Lower cure rate and poor prognosis of cancer patients are closely related to these ten characteristics of cancer. These ten characteristics make cancer more mysterious within the complex tumor microenvironments.

\section{Cancer-associated fibroblasts (CAFs)}

A sub-population of fibroblasts with a myofibroblastic phenotype in cancerous wounds is distinguished as cancer-associated fibroblasts (CAFs). After activation, fibroblasts are known as CAFs or myofibroblasts [34-36]. During natural wound repair, myofibroblasts are transiently present [37]. Unlike the process of wound healing, CAFs at the site of a tumor remain perpetually activated, as in tissue fibrosis.

Several studies have demonstrated that only the activated fibroblasts are required to initiate and promote tumor growth [38-40]. Fibroblast activation may be induced through various impetuses when tissue lesions occur, including growth factors, direct cell-cell communication, adhesion molecules contacting with leukocytes, reactive oxygen species [41], and microRNA [42, 43]. When the fibroblasts remain activated after the initial insult has regressed, these activated fibroblasts may work with other molecular pathways to boost neoplasm initiation. These CAFs have a significant impact on cancer progression through remodeling ECM, inducing angiogenesis, recruiting inflammatory cells, and directly stimulating cancer cell proliferation via the secretion of growth factors, immune suppressive cytokines, and mesenchymal-epithelial cell interactions [41, 44]. For instance, Galectin-1 overexpression in CAFs advances the development of abutting cancer cells [45] and is correlated with poor prognosis in several types of cancer, including breast and prostate cancer and laryngeal carcinoma [46-49]. Chemokine (C-X-C motif) ligand 12 (CXCL12), violently uttered in CAFs, may induce epithelial-mesenchymal transition (EMT) of cancer cells to promote cancer progress in gastric and prostate cancers [50, 51]. Moreover, one team discovered that MMP-2, derived from senescent CAF-CMs, induced epithelial invasion and keratinocyte discohesion into collagen. Interleukin-22 (IL-22) is also expressed by CAFs to encourage gastric cancer cell invasion through STAT3 and ERK signaling [52]. Using a 3D invasion model, another study found that HCT116 cells manifested a substantially invasive phenotype, while media originated from human dermal fibroblasts (HDF) [53].

Since myofibroblasts can be distinguished by alpha-smooth muscle actin (a-SMA), laminin-1, transforming growth factor beta (TGF- $\beta 1$ ), vascular endothelia growth factor A (VEGF-A), etc. [54, 55], CAFs have been recognized as playing an essential role in the metastasis and development of cancer [56]. Oncologists have found that through HGF, TGF- $\beta$, platelet-derived growth factor (PDGF) etc., CAFs may promote tumor growth and invasion (Figure 2). Through fibroblast growth factor 2 (FGF2), VEGF, etc., CAFs may promote tumor development by promoting angiogenesis [57]. Additionally, CAFs also interact with immune-inflammatory cells and neuroendocrine cells through different cell factors and cytokines to jointly promote the initiation, progression, and invasion of cancer [58-62]. However, many of the markers that have been gradually proven to be unable to identify all of the CAFs, are not unique to the CAFs [63]. The cardinal functions and the primary markers of CAFs are illustrated in Table $\mathbf{1}$. For instance, a-SMA, one of the previous major markers of CAFs, was found to be expressed in normal fibroblasts [64], pericytes, and smooth muscle 
cells [65]. The cell-surface serine protease fibroblast activation protein a (FAPa), which is highly expressed in quiescent mesodermal cells in multiple tissue types [66], is also not specific to CAFs. Additional markers fibroblast-specific protein 1 (FSP-1) [67], vimentin, and certain proteins, including NG2 (Neuroglial Antigen-2), platelet-derived growth factor receptor- $\beta$ (PDGFR- $\beta$ ), fibroblast-associated antigen, and prolyl 4-hydroxylase have been shown to be expressed in cells other than CAFs [63].

Table 1. The function of cell players in the tumor microenvironment.

\begin{tabular}{|c|c|c|}
\hline Cell players & Main markers & Primary functions \\
\hline $\begin{array}{l}\text { Cancer-associated } \\
\text { fibroblasts (CAFs) }\end{array}$ & $\begin{array}{l}\text { PDGF* }^{*} \text { FAP*; } \\
\text { FGFR }^{*} ; \text { VDR }^{*}\end{array}$ & $\begin{array}{l}\text { Regulating inflammation; } \\
\text { Participating in wound healing; } \\
\text { Integrating collagen and protein to } \\
\text { form the ECM fiber network; } \\
\text { Escaping damage; }\end{array}$ \\
\hline $\begin{array}{l}\text { Immune \& } \\
\text { Inflammatory cell }\end{array}$ & $\begin{array}{l}\text { TNF-a; IL-10; IL-12; } \\
\text { TGF- } \beta \text {; Foxp3+*; } \\
\text { HMGB1*; CD163+*; } \\
\text { KIR*; PD-1+* }^{*}\end{array}$ & $\begin{array}{l}\text { Treatment of wound healing and } \\
\text { infection; Clearing dead cells and } \\
\text { cellular debris; Having a double } \\
\text { effect on tumor formation }\end{array}$ \\
\hline $\begin{array}{l}\text { The blood \& } \\
\text { lymphatic } \\
\text { vascular } \\
\text { networks }\end{array}$ & $\begin{array}{l}\text { VEGRF3; LYVE-1; } \\
\text { CD31; CD34; VEGF*; } \\
\text { PlGF*; VEGF-B*; } \\
\text { VEGF-C*; VEGF-D* }\end{array}$ & $\begin{array}{l}\text { Require nutrients and oxygen; } \\
\text { Evacuating metabolic wastes and } \\
\text { carbon dioxide; Helping to escape } \\
\text { immune surveillance. }\end{array}$ \\
\hline Adipose cell & $\mathrm{AIs}^{*} ; \mathrm{MBD6}^{*}$ & $\begin{array}{l}\text { Producing circulating blood } \\
\text { estrogen; A major energy source; } \\
\text { Relating with inflammation; } \\
\text { Recruiting immune cells; Support } \\
\text { vasculogenesis. }\end{array}$ \\
\hline $\begin{array}{l}\text { Neuroendocrine } \\
\text { cell }\end{array}$ & $\begin{array}{l}\text { NSE; CgA; K18\&K8 } \\
\text { cytokeratins; PGP9.5; } \\
\text { Ki-67; IL-2; KE108*; } \\
\text { DLL3*; EGF* }^{*}\end{array}$ & $\begin{array}{l}\text { Extending lumina and adjacent } \\
\text { epithelial cells; Regulating } \\
\text { secretion and motility; Controlling } \\
\text { lung branching morphogenesis; } \\
\text { Providing a protective niche for a } \\
\text { subset of lung stem cells. }\end{array}$ \\
\hline
\end{tabular}

Note: ${ }^{*}$, the targeting markers.

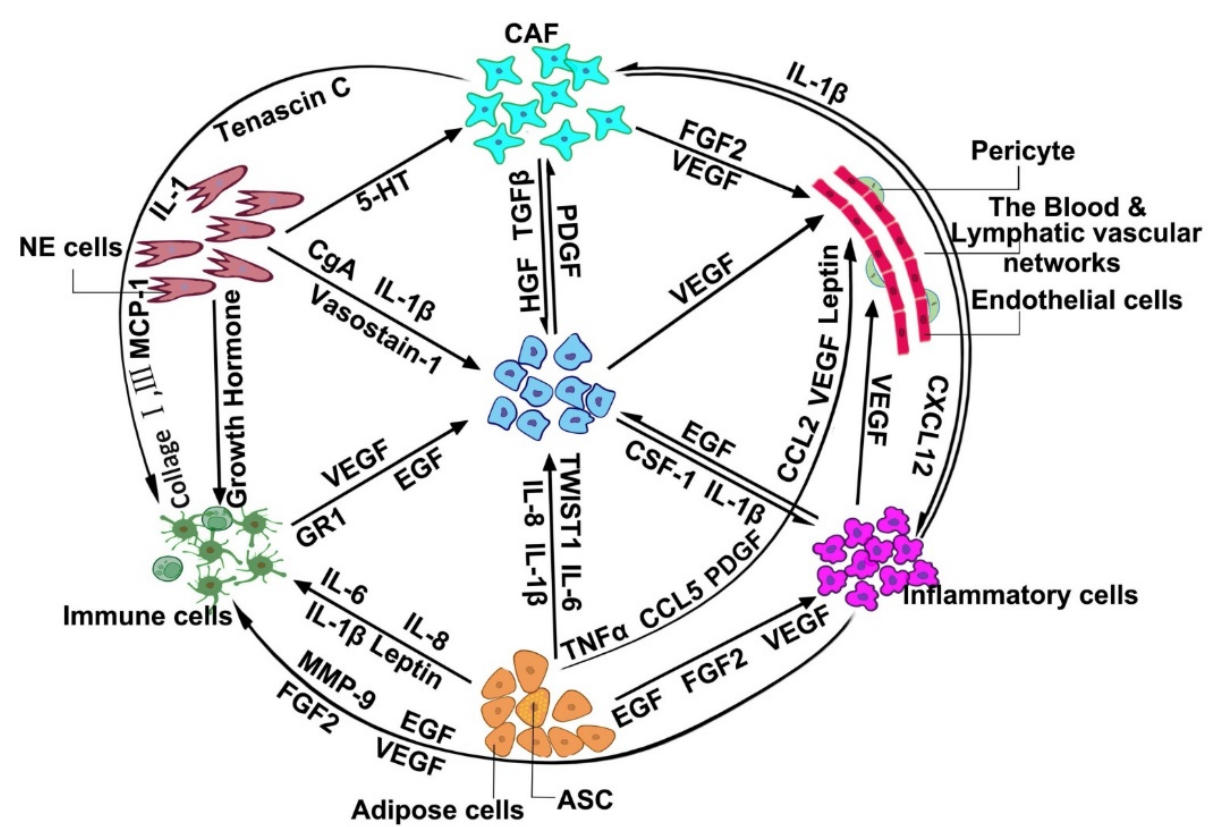

Figure 2. The inactive network of cancer cells and the tumor microenvironment.
Similarly, although there is no unique marker, there are still some targets for significant help in cancer treatment. CAFs work in two main ways in cancer treatment. One method is by directly reversing CAFs into the normal fibroblasts or inhibiting their growth. This method highlighted that efforts such as reconstituting miRNA expression had been proven to deactivate CAFs [68-70] and inhibit PDGF signaling in the mouse model of cervical carcinogenesis; it can also reduce tumor proliferation [71]. Additionally, the fibroblast growth factor receptor (FGFR) signaling pathway may be one of the therapeutic objectives in gastric cancer [72].The other objective is dedifferentiating CAF into a quiescent state. One data set showed that Vitamin D receptor (VDR) ligands promoted the dedifferentiation of satellite cells and abrogated fibrosis [73]. Using a murine xenograft model of colon carcinoma, another recent study found that when targeting fibroblast activation protein (FAP), the accumulation of CAFs was markedly reduced [74]. FAP is expected to become another marker of CAFs targeted therapy.

\section{Immune and inflammatory cell}

The main function of the mammalian immune system is to monitor tissue homeostasis, to protect against invading or infectious pathogens and to eradicate damaged cells [75]. The primary theory advises that immune surveillance has significant roles in recognizing and eradicating a large part of nascent tumor cells [1]. However, unlike normal functions, immune-inflammatory cells would persist in sites of chronic inflammation, linked to diverse tissue pathologies, including fibrosis, aberrant angiogenesis, and neoplasia [76]. In light of recent discoveries in immune system research, it is difficult to ignore the crucial issue that immune-inflammatory cells may be the early cradle of cancer [77-83].

Several studies have revealed the contribution of adaptive and innate immunity in cancer immunoediting, including the unmanipulated innate immune system without adaptive immunity [84]. Dunn et al. divided the dynamic process of cancer immunoediting into three steps: elimination, 
equilibrium, and escape [85]. These three stages can also be used to express the role of the immune system in cancer initiation, progression, and invasion. He pointed out that in the elimination phase, the immunologic system can defeat nascent tumors. This is accomplished by different inflammatory cells [86-88] and signaling molecules [88, 89]. Once cancer cells have been completely eliminated, these active factors and immune cells may have an additional role in producing "immunologic sculpting" or "immunoediting" [85]. This means that in the equilibrium stage, tumor cells cannot be completely cleared, but the tumor growth can controlled. In order to escape the immune surveillance, cancer cells tend to evolve a number of phenotypic changes in this stage, such as EMT [90]. These cells, with survival advantage, would eventually develop into the primary solid tumor. In other words, the immune microenvironment helps cancer cells to select the dominant cells so that the tumor can progress at the fastest rate in a limited environment. Several studies in mice have revealed that the depletion of macrophages during tumor induction restrained tumor growth $[91,92]$. Regarding the escape stage, the immune system may help tumor cells to format the clinical characterization of tumor immune escape mechanisms, while many experiments have proven that immune cells can reduce anti-cancer proteins or cytokines to promote cancer invasion [93, 94]. In addition, one experiment also found that immune cells may be related to the regulation of apoptosis [95]. However, the greatest divergence between these transitional immune cells and the other stroma cells is that these immune cells can be redesigned toward the tumor destruction in therapies. How to activate the normal function of immune cells will be the focus of a future study.

As depicted in Figure 2, CAFs [96], NE cells [97], adipose cells [98-100], and inflammatory cells [101-103] in the TME can affect the role of immune cells through the secretion of different cytokines, cell factors, or interacting proteins, which adds several difficulties to the search for markers and targets for cancer therapy [104, 105]. In different cell and tumor types, the complexity and heterogeneity of immune factors also provides a further complication to finding more specific markers of the immune cells. The immune system is divided into adaptive immunity and innate immunity. Adaptive immune cells include thymus-dependent lymphocytes ( $\mathrm{T}$ cells), and bursa-dependent lymphocytes (B cells). Innate immune cells consist of dendritic cells (DC), killer lymphocytes, natural killer (NK) cells, hyaline leukocyte/macrophage, granulocytes, and mast cells [106]. According to the different clusters of differentiation, $\mathrm{T}$ cells are divided into $\mathrm{CD} 4^{+} \mathrm{T}$ (helper $\mathrm{T}$ cells, Th) and $\mathrm{CD} 8^{+} \mathrm{T}$ (cytotoxic $\mathrm{T}$ cells, $\mathrm{Tc}$ ) cells. These secrete IFN- $\gamma$, TNF- $\alpha$, and IL17, which have antitumor effects. B cells are mainly marked by different antigens in different physiological periods, such as mainly expressing CD19 and CD20 in pre-B cells, immature B cells, and plasma cells, mainly expressing IgM, IgD, and CR1 in mature $B$ cells, and mainly expressing IgM, IgD, IgA, IgG in memory B cells. A key feature of human NK cells, which could efficiently recognize infected and malignant target cells, is the expression of HLA class I-specific receptors of the KIR and NKG2 gene families [107]. DCs express co-stimulatory molecules and innate inflammatory cytokines, such as IL-12, IL-23, and IL-1, that promote IFN- $\gamma$-secreting $\mathrm{CD}^{+} \mathrm{T}$ cells and cytotoxic $\mathrm{T}$ lymphocyte responses [108]. DCs represent key targets for 1,25-dihydroxyvitamin $\mathrm{D}_{3}$ $\left(1,25(\mathrm{OH})_{2} \mathrm{D}_{3}\right)$, which can directly induce T cells [109].

After the addition of immune-inflammatory cells into an emerging hallmark of cancer [1], studies have shown that immune cells were associated with immunosuppression. Some types of immune cells have an innate function of immune suppression, and some cytokines can also activate them through different signaling pathways. The main immunosuppressive cells are regulatory $\mathrm{T}$ (Treg) cells marked by Foxp3 ${ }^{+}$[110], myeloid-derived suppressor cells (MDSC) marked by HMGB1 [111], and M2 macrophages marked by $\mathrm{CD} 163^{+}[108,112]$, which have emerged as a leading method in the development of new immunotherapeutics. Studies have also found that some granulocytes can promote cancer development through the expression of cytokines, such as the hematopoietic growth factor (HGF), granulocyte colony-stimulating factor (G-CSF), or inducing changes in stromal cells [113-115]. PD-1 ${ }^{+}$and cytotoxic T-lymphocyte antigen-4 (CTLA-4) expressed by "exhausted" CD8 ${ }^{+} \mathrm{T}$ cells are also targeting markers in treating patients with breast and non-small cell lung (NSCL) cancer [116-118]. In addition to the mutual activation [119], the antitumor effects also can be suppressed by some co-inhibitory molecules expressed by antitumor immune cells, such as PD-1/PD-L1 [120, 121]. Some antitumor cytokines can also promote immunosuppression, such as IL-10 and TGF- $\beta$ secreted by DCs, which may activate Treg cells that are recruited to the tumor under the influence of the chemokines, including CCL22 and CXCL12 [108]. As for these immunosuppressive cells, cell depletion strategies [122-125], tumor vaccines [126], intratumoral injection with an agonistic antibody [127], targeting the transcription factor, and suppression of activated receptors [128, 129] have 
been widely used in improving immune surveillance and promoting antitumor immune responses. Agonist antibodies of CD40, 4-1BB, GITR, and OX-40 can also be used to enhance antigen-specific $\mathrm{T}$ cell responses [130], CD25 antibody can be used to reduce the number of Treg cells or inhibit Treg function [131], and promote the maturation of DC and rational use of cytokines and antibodies to break the immune tolerance [132]. The significant roles and the master markers of the immune and inflammatory cells are indicated in Table 1.

\section{The blood and lymphatic vascular networks}

Similar to normal tissues, the blood and lymphatic vascular networks supply oxygen and sustenance as well as removing carbon dioxide and metabolic wastes for sustaining the survival of neoplasm growth. These networks have two main features. First, the new vessels surrounding tumors are usually inefficient, tortuous, or leaky [133]. Second, the angiogenic switch is almost always activated and remains active during the process of the tumorigenesis, resulting in continued growth of new natural blood vessels [134]. In the tumor angiogenesis process, new blood vessels form from pre-existing vessels, making the blood and lymphatic vascular network more complex [135].

The blood and lymphatic vascular networks have different roles during the stages of tumorigenesis [136]. Tumor normal cells are confronted with the challenge of hypoxic surroundings [137]. To survive in hypoxic circumstances, primary tumor cells may adjust to the low oxygen setting, or migrate to and recruit blood vessels [138]. A selection shape can be chosen, which is more enterprising and metastatic, and is provided by a chronically hypoxic environment [139, 140]. In the process of tumor progression, one of the primary functions of the blood and lymphatic vascular networks is to help tumor cells escape immune surveillance. Escape measures are mainly divided into two categories. Directly, the lymphatic microenvironment will weaken or eliminate the normal function of immune cells. For instance, the myeloid-derived suppressor cells (MDSCs) and the immature DCs in the sentinel lymph nodes (SLNs) could restrict the normal operation of T cells [141-143]. When the metastatic tumor enters a novel environment, $\mathrm{CD} 4^{+}$and $\mathrm{CD} 8^{+} \mathrm{T}$ cells may help them to evade the host immune system [144, 145]. The remodeling of unusual endothelial venules (HEVs) can indirectly influence immune cells to traffic into lymph nodes [146]. Though some immune cells traffic into the lymph nodes through the draining afferent lymphatic vessels, lymphocyte recruitment into the SLN via HEVs is fundamental [144].

Moreover, lymphatic vessels around the tumor also provide a physical link between the SLNs and primary tumor. When lymphatic vessels are obstructed, collateral lymphatic vessels can make up for the diminution in lymphatic capacity [144, 147]. This physical connection is like a highway through which tumor cells can reach other locations. Some phenomena showed that local tumor invasion correlated with excellent lymphatic vessel density in the tumor margin [148, 149]. Figure 2 shows that through different interacting factors, adipose cells, inflammatory cells, and CAFs can also closely connect with lymphatic vascular networks [150-153]. The physical and chemical connection makes the role of angiogenesis in tumor formation more of a mystery.

The important functions and the primary markers of the blood and lymphatic vascular networks are listed in Table 1. Banerji et al. found that the lymphatic vessel endothelial HA receptor (LYVE-1) was expressed predominantly in lymphatic vessels [154]. Evidence suggests that VEGF is among the most important factors for anti-angiogenic treatment $[155,156]$. A number of studies have discovered that VEGF would inhibit the development of new vessels, block the VEGF or its signaling pathways, prune pre-existing vessels, and induce vessel normalization [133, 157, 158]. Furthermore, clinical trials that targeted VEGF and other markers showed prolonged survival $[155,159]$. Members of the VEGF family include placental growth factor (PlGF), VEGF-B, VEGF-C, and VEGF-D, which were also good candidates for anti-angiogenic treatment [133, 160-164]. Another marker, PDGF $\beta$, secreted by sprouting ECs, has two sides of the effects on tumors. It would recruit prostate cancer (PC) signaling through the presenting PDGF receptor- $\beta$ (PDGFR $\beta$ ) [165]. Studies have revealed that blockage of PDGF $\beta$ makes tumor vessels more sensitive to VEGF inhibitors [166, 167]. Consequently, the decrement of PDGF $\beta$ also enhances the risk of increased metastasis [158]. Generally, anti-PDGF $\beta$ drugs play an auxiliary role in anti-VEGF treatment. Some other markers, such as CRISP-3 [94], CCR7 [168], GATA2 [169], Prox1 [170], and Foxc2 [171] have also been found and are well used in the treatment. In conclusion, abnormal tumor vasculature exhibited remarkable spatiotemporal heterogeneousness, and not only damaged perfusion and drug delivery, but also made chemoradiotherapy less expeditious.

\section{Adipose cells}

Adipose tissue comprises two cell types, white adipose tissue (WAT) and adipocytes [172]. The 
significant functions and major markers of adipose cells are shown in Table 1. Extensive evidence has proven that some features of adipose tissue are associated with cancer. First, obese adipose tissue hypoxia establishes a highly proinflammatory microenvironment, which is more likely to breed tumors [173-175]. Second, adipose cells also secrete more than 50 different cytokines, chemokines, and hormone-like factors [176, 177]. These factors, whose production may upregulate in obesity, may be accomplices in tumor initiation. Similar to interleukin (IL)-6, IL-8, IL-1 $\beta$, tumor necrosis factor- $\alpha$ (TNF-a), VEGF, chemokine (C-C motif) ligand 2 (CCL2) and CCL5 [178, 179]. Third, in obese patients, adipose tissue accommodates a higher proportion of preadipocytes, in which figures of macrophages and monocytes synergistic increase [180]. These alterations may also contribute to cancer development locally. Fourthly, adipose tissue reprogramming and the associated systemic secretion may have an effect on cancer growth and progression [180]. Excess adiposity leads to high circulating blood estrogen [181] and chronic, low-grade inflammation, which is involved in cancer development [176, 182-184]. Cancer progression has been proven to be accompanied by recruiting progenitor mesenchymal stromal cells (MSCs) in reaction to setting factors free by TME with hypoxic and inflammatory conditions $[185,186]$.

Another type of cancer-associated adipose cell is the adipose stem cells (ASC), which have the capability to differentiate into multiple cell lineages [187-189]. ASC plays a chief role when it comes to the promotion of tumor progress. First, ASCs influence the tumor microenvironment (Figure 2). Eterno et al. [190] suggested that ASCs may worsen the tumorigenic behavior of c-Met-producing breast cancer cells by creating a TME characterized by inflammation. The TGF $\beta 1$ signaling pathway may also play a role in the interaction between ASCs and the TME [98]. Second, ASCs may promote angiogenesis [191]. Gehmert et al. [192] reported that ASCs might contribute to angiogenesis by migrating toward tumor-conditioned media through the platelet-derived growth factor $\mathrm{BB} /$ platelet-derived growth factor receptor- $\beta$ (PDGF-BB/PDGFR- $\beta$ ) signaling pathway[193]. Third, ASCs may differentiate into carcinoma-associated cells. In breast-cancer tumor models, many studies have found that ASCs may differentiate into fibroblasts and promote tumor proliferation [194]. The same findings were also reflected in ovarian cancer and lung cancer progression [195-198]. Fourth, ASCs may promote EMT. Studies using pleural effusions or established breast cancer cell lines from breast cancer patients exemplified that either co-culture with ASCs or conditioned medium from could advance invasion and EMT of breast cancer cells [199-201].

Cancers are triggered by adipocytes to gain enterprising tumor phenotypes with some aggressive traits. In turn, cancer cells may express the corresponding markers. Although there is no unique marker for clinical identification, the increase or decrease in the number of a substance in adipose tissue may directly or indirectly reflect the initiation, progression, and invasion of the tumor, such as the EMT-like phenotypic alterations accompanied by the upregulation of matrix metallopeptidase 9 (MMP9) and TWIST1 $[202,203]$. Higher aromatase activity and higher degrees of obesity may abate the efficacy of aromatase inhibitors [204]. Leptin, an adipocyte-derived cytokine, would arouse proliferation in some cell types, such as mammary epithelium, which has an effect on the neoplasm cell proliferation, apoptosis, and cell cycle [205-207]. Data has shown that high glucose levels can induce leptin signaling directly [208]. Additionally, adiponectin in given cells may inhibit proliferation promoting apoptosis through the adenosine monophosphate kinase (AMPK) and MAPK pathways [180].

Certain types of cancer have found adipose-related target markers. For instance, methyl-CpG-binding protein 6 (MBD6) is a direct target of octamer-binding transcription factor 4 (Oct4) and controls the stemness and differentiation of adipose tissue-derived mesenchymal stem cells (ASC)[209]. Aromatase is one of the newly discovered adipose-related markers for postmenopausal breast cancer. The majority of postmenopausal breast cancers are estrogen receptor (ER)-positive. Obesity results in the secretion of inflammatory factors, which stimulates the expression of the aromatase enzyme and converts androgens into estrogens in the adipose tissue [210]. Several clinical trials have revealed that many pathways could be targeted to specifically inhibit aromatase within the breast. For example, through targeting aromatase inhibitors (AIs), clinical treatment may inhibit the activity of aromatase enzymes and prevent estrogen production [211]. Although targeted therapy has achieved promising results, it also has certain side effects.

\section{Neuroendocrine cell}

In the late 1920s, Siegfried Oberndorfer found that the secretion of nerve cells in the hypothalamus enters the blood [212]. These cells are now called neuroendocrine (NE) cells, and a series of experiments proved that this type of cell exhibits a combination of neuronal and endocrine features [56]. In healthy organisms, normal NE cells play complex local 
regulatory roles at the tissue level [213]. NE cells are part of the diffuse NE system, which is spread throughout the normal organism. They can also be found within endocrine glands or tissues, such as the hypothalamus, anterior pituitary gland, pineal gland, thyroid gland (calcitonin-secreting cells), thymus, breast, and the pancreatic islets of langerhans [212, 214, 215]. Under the electron microscope, two different morphologies were found: open-type cells and closed-type cells [212]. There is no difference in the location of these two kinds of cells, but the function is not the same, which increases the difficulty in studying NE cells.

NE cells are the accomplices of tumor formation [216]. Extensive evidence has proven that the NE system strongly influences the function of the immune system (Figure 2). The NE system can regulate the migration and cytotoxicity in NK cells through neurotransmitters [217]. Additionally, substance $\mathrm{P}$ showed the ability to block the $\beta 1$-integrin-mediated adhesion of $\mathrm{T}$ lymphocytes [218] and increase their migratory activity [219]. Substance $\mathrm{P}$ also can induce the production of various cytokines in leukocytes [220]. Norepinephrine, another neurotransmitter, also showed a significant impact on T cells [219]. It could inhibit the generation of antitumor cytotoxic T-lymphocytes (CTLs) through the inhibition of TNF-a synthesis [221]. On the other hand, as a result of their secretory products, NE cells could stimulate the proliferation of prostate carcinoma cells and increase their aggressiveness [222], while in the development of NE-cell tumors, NE cells may play a leading role [223]. NE carcinomas are rare malignancies that originate from the hormone-producing cells of the body's NE system. While there is no conclusive evidence, several studies have reflected on this conclusion. For example, one result showed that androgen-dependent lymph node carcinomas of the prostate (LNCAP) could only develop in the presence of NE tumors in castrating mice, which proved that NE tumor cells may secrete specific factors [224]. NE tumors had a highly internal heterogeneity, and there were 13 different types of NE cells [225]. Different NEs produce different secretions, which leads to different or mixed symptoms. NE tumors are also highly aggressive. Approximately $50 \%$ of pancreatic NE tumors have hepatic metastases [226] due to the secretion of several peptide hormones. To improve the survival rate of NE tumors, it is becoming more and more urgent to find specific markers.

The significant functions and the major markers of NE are shown in Table 1. Many markers have gradually been found to be expressed in a large number of prostatic NE cancer cases[227], such as K18 and $\quad \mathrm{K} 8 \quad$ cytokeratins [228], a-methylacyl-CoA-racemase (AMACR) [228], plasma anterior gradient 2 (AGR2) [229], and PGP9.5 [230]. Additionally, neuron-specific enolase (NSE) and chromogranin A ( $\mathrm{CgA})$ may be the most frequently expressed neuropeptides [231-233], but they also have limitations in sensitivity, specificity, reproducibility, etc. [234]. IL-2 was more specific than any marker other than Ki-67 in detecting gastroenteropancreatic NE tumors [235], even though some other targeting markers were promising for use in clinical treatment. Novel TDP-A-loaded and KE108-conjugated unimolecular micelles exhibited the best potential in suppressing NE cancer cell growth both in vitro and in vivo [236]. There also have also been some achievements in the fields of prostate, lung, pancreas, and gastrointestinal tracts. Delta-like canonical notch ligand 3 (DLL3) proteins are expressed on the surface of pulmonary NE tumor cells but not in normal adult tissues. One multiple model in vivo showed that a DLL3-targeted antibody-drug induced durable tumor regression [237]. In addition, more than $85 \%$ of lung cancer patients are diagnosed with NSCLC, while the other $15 \%$ are classified as small cell lung cancer (SCLC) [238, 239]. All the SCLC patients show histological features of NE morphology. Synaptophysin (Syn), and neural cell adhesion molecule 1 (NCAM1) are known as NE diagnostic markers. One recently study result showed that the positive expression rates of these three markers were $112(58.3 \%), 160(83.3 \%)$, and $166(86.5 \%)$, respectively, in a total of 192 SCLC patients [240]. In addition to targeted therapy, peptide receptor radionuclide therapy is a promising new treatment modality for inoperable or metastasized gastroenteropancreatic NE tumors patients [241]. Some studies have found that EGF receptor inhibition may disrupt some signaling cascades, which may inhibit the growth of foregut NE tumors/pancreatic NE tumors [242]. Another result also proved that PRCRT is an effective treatment in patients with FDG-avid NE tumors, even in patients for whom conventional therapies have failed[243]. Recent genomic profiling studies, which have demonstrated that prostate cancers with an NE phenotype are enriched for loss of RB, loss or mutation of TP53, loss of AR, and AR target gene expression, and overexpression of MYCN and AURKA, may also provide a new treatment method [244].

\section{ECM within the microenvironment}

ECM, a dynamic and complicated environment, is characterized using biophysical, mechanical and biochemical properties specific for each tissue. ECM contains all the cytokines, growth factors, and 
hormones secreted by stromal and tumor cells. Many assays have respectively demonstrated ECM components, including collagens [245-247], laminins [248], fibronectins [249], proteoglycans [250], and hyaluronans [251, 252] in a specific organization [225]. In vitro, one three-dimensional (3D) model indicated that ECM heterogeneity is crucial for controlling collective cell invasive behaviors and determining metastasis efficiency [253-262]. Because of the complexity of ECM heterogeneity in vivo, its influence on collective cell behavior has been described but not quantified [253].

Depending on the different organization and locations, ECM has complementary effects on the development and metastasis of tumors in diverse ways. First, ECM may affect tumors through extracellular secretion. During embryogenesis, fibroblastic mesenchyme determines the sexual phenotype of the gland, while the adipocyte mesenchyme controls mammary-specific ductal morphogenesis [263-266]. One study illustrated that innate ECM scaffolds, derived from decellularized tissues, lead the cells derived from stem cell differentiation that reside in the tissue from which the ECM was derived [267]. Second, ECM may alter the phenotype type of stromal cells or tumor cells. Oncogenic mutations are broadly thought to increase cellular fitness and result in the clonal expansion of receivers. One experiment revealed that the ability to clean apoptotic colon cancer cells can be promoted by tumor-associated macrophages (TAMs) through the expression of sulfoglycolipids (SM4s). During this procedure, phenotypic change of TAM was accompanied by expression of TGF- $\beta 1$ and secretion of IL-6, which may have an advantage in further activating the angiogenic process [268]. Third, ECM can help neoplasms to get away from immune surveillance. For instance, colon cancer cells always display an increased production of Fas ligand binding to its receptor on immune cells [269]. Fourth, the ECM tumor will provide a hypoxic or acidic environment in which the tumor cells have greater survival advantages than normal cells. ECM will select survival cells to aid in tumor growth and invasion at the fastest rate.

\section{Conclusion}

Tumor management strategies include surgery for a cure or for cytoreduction, radiological intervention, chemotherapy, and somatostatin analogs to control symptoms. However, tumor cells are extremely elastic and may adapt to treatments and environmental modifications speedily [270-277]. Once one component has been obstructed, other mechanisms will quickly follow. This may be one of the main factors that lead to poor prognosis. The major interaction between different stromal cells and active factors in the advanced TME is shown in Figure 2. Different impeding mechanisms at the same time might lead to the best results of tumor development. In other words, it is important to understand the role of different components of the TME in the treatment and prevention of tumors. Moreover, the study of predictive biomarkers, which may fully address the complexities of the biology, will promote the development of therapies tailored to individual patients. At present, the emerging targeted microenvironment therapy has been widely accepted. According to the characteristics of different tissues, the synergistic therapies targeting multiple microenvironment stromal cells and the continuous discovery of multiple target markers may be the direction of future research.

\section{Acknowledgement}

This work was supported in part by grants from the National Natural Science Foundation of China (81372907, 81301757, 81472531, 81402009, 81572787, 81672993 and 81672683), the Natural Science Foundation of Hunan Province (14JJ1010, 2015JJ1022 and 2016JC2035), the Hunan Provincial Development and Reform Commission (422030001), the Open-End Fund for the Valuable and Precision Instruments and the Faculty Research Fund of Central South University (CSUZC201739), the Mittal Innovation Foundation of Central South University (15MX46, MX2016442), and the Fundamental Research Funds for Central Universities of Central South University (2014zzts066, 2016zzts478)

\section{Competing Interests}

The authors have declared that no competing interest exists.

\section{References}

1 Hanahan D, Weinberg RA. Hallmarks of cancer: the next generation. Cell. 2011; 144: 646-74.

2 Xiong W, Zeng ZY, Xia JH, et al. A susceptibility locus at chromosome 3p21 linked to familial nasopharyngeal carcinoma. Cancer Res. 2004; 64: 1972-4.

3 Zeng Z, Zhou Y, Zhang W, et al. Family-based association analysis validates chromosome 3 p21 as a putative nasopharyngeal carcinoma susceptibility locus. Genet Med. 2006; 8: 156-60.

4 Zeng Z, Zhou Y, Xiong W, et al. Analysis of gene expression identifies candidate molecular markers in nasopharyngeal carcinoma using microdissection and cDNA microarray. J Cancer Res Clin Oncol. 2007; 133: 71-81.

5 Zeng ZY, Zhou YH, Zhang WL, et al. Gene expression profiling of nasopharyngeal carcinoma reveals the abnormally regulated Wnt signaling pathway. Hum Pathol. 2007; 38: 120-33.

6 Zhou Y, Zeng Z, Zhang W, et al. Identification of candidate molecular markers of nasopharyngeal carcinoma by microarray analysis of subtracted cDNA libraries constructed by suppression subtractive hybridization. Eur J Cancer Prev. 2008; 17: 561-71.

7 Zhou Y, Zeng Z, Zhang W, et al. Lactotransferrin: a candidate tumor suppressor-Deficient expression in human nasopharyngeal carcinoma and inhibition of NPC cell proliferation by modulating the mitogen-activated protein kinase pathway. Int J Cancer. 2008; 123: 2065-72. 
8 Zeng $\mathrm{Z}$, Huang $\mathrm{H}$, Zhang $\mathrm{W}$, et al. Nasopharyngeal carcinoma: advances in genomics and molecular genetics. Sci China Life Sci. 2011; 54: 966-75.

9 Gong Z, Zhang S, Zhang W, et al. Long non-coding RNAs in cancer. Sci China Life Sci. 2012; 55: 1120-4

10 Zhang W, Zeng Z, Fan S, et al. Evaluation of the prognostic value of TGF-beta superfamily type I receptor and TGF-beta type II receptor expression in nasopharyngeal carcinoma using high-throughput tissue microarrays. J Mol Histol. 2012; 43: 297-306.

11 Liao Q, Guo X, Li X, et al. Prohibitin is an important biomarker for nasopharyngeal carcinoma progression and prognosis. Eur J Cancer Prev. 2013; 22: 68-76.

12 Zhang W, Huang C, Gong Z, et al. Expression of LINC00312, a long intergenic non-coding RNA, is negatively correlated with tumor size but positively correlated with lymph node metastasis in nasopharyngeal carcinoma. J Mol Histol. 2013; 44: 545-54.

13 Zeng Z, Huang H, Huang L, et al. Regulation network and expression profiles of Epstein-Barr virus-encoded microRNAs and their potential target host genes in nasopharyngeal carcinomas. Sci China Life Sci. 2014; 57: 315-26.

14 Bo H, Gong Z, Zhang W, et al. Upregulated long non-coding RNA AFAP1-AS1 expression is associated with progression and poor prognosis of nasopharyngeal carcinoma. Oncotarget. 2015; 6: 20404-18.

15 Zhang W, Fan S, Zou G, et al. Lactotransferrin could be a novel independent molecular prognosticator of nasopharyngeal carcinoma. Tumour Biol. 2015; 36: 675-83.

$16 \mathrm{Li} \mathrm{H}, \mathrm{Li} \mathrm{X}$, Ge X, et al. MiR-34b-3 and miR-449a inhibit malignant progression of nasopharyngeal carcinoma by targeting lactate dehydrogenase A. Oncotarget. 2016; 7: 54838-51.

17 Li Q, Chen P, Zeng Z, et al. Yeast two-hybrid screening identified WDR77 as a novel interacting partner of TSC22D2. Tumour Biol. 2016; 37: 12503-12.

18 Liang F, Li Q, Li X, et al. TSC22D2 interacts with PKM2 and inhibits cell growth in colorectal cancer. Int J Oncol. 2016; 49: 1046-56.

19 Wang H, Zhao R, Guo C, et al. Knockout of BRD7 results in impaired spermatogenesis and male infertility. Sci Rep. 2016; 6: 21776

20 Wang Y, Xue D, Li Y, et al. The Long Noncoding RNA MALAT-1 is A Novel Biomarker in Various Cancers: A Meta-analysis Based on the GEO Database and Literature. J Cancer. 2016; 7: 991-1001.

$21 \mathrm{Xu} \mathrm{K}$, Xiong W, Zhou M, et al. Integrating ChIP-sequencing and digital gene expression profiling to identify BRD7 downstream genes and construct their regulating network. Mol Cell Biochem. 2016; 411: 57-71.

22 Yu J, Liu Y, Gong Z, et al. Overexpression long non-coding RNA LINC00673 is associated with poor prognosis and promotes invasion and metastasis in tongue squamous cell carcinoma. Oncotarget. 2017; DOI: 10.18632/oncotarget.14200.

23 Zeng Z, Fan S, Zhang X, et al. Epstein-Barr virus-encoded small RNA 1 (EBER-1) could predict good prognosis in nasopharyngeal carcinoma. Clin Transl Oncol. 2016; 18: 206-11.

24 Zhou Y, Liao Q, Li X, et al. HYOU1, Regulated by LPLUNC1, Is Up-Regulated in Nasopharyngeal Carcinoma and Associated with Poor Prognosis. J Cancer. 2016; 7: 367-76

25 Liu Y, Zhao R, Wang H, et al. miR-141 is involved in BRD7-mediated cell proliferation and tumor formation through suppression of the PTEN/AKT pathway in nasopharyngeal carcinoma. Cell Death Dis. 2016; 7: e2156.

26 Wang W, Yi M, Chen S, et al. Significance of the NOR1-FOXA1/HDAC2-Slug regulatory network in epithelial-mesenchymal transition of tumor cells. Oncotarget. 2016; 7: 16745-59.

27 Wang W, Yi M, Chen S, et al. NOR1 Suppresses Cancer Stem-Like Cells Properties of Tumor Cells via the Inhibition of the AKT-GSK-3beta-Wnt/beta-Catenin-ALDH1A1 Signal Circuit. J Cell Physiol. 2017; DOI: 10.1002/jcp.25706.

28 Yang L, Tang Y, He Y, et al. High Expression of LINC01420 indicates an unfavorable prognosis and modulates cell migration and invasion in nasopharyngeal carcinoma. J Cancer. 2017; 8: 97-103.

29 Tang Y, He Y, Yang L, et al. Co-expression of AFAP1-AS1 and PD-1 predicts poor prognosis in nasopharyngeal carcinoma. Oncotarget. 2017;

30 Wang Y, Mo Y, Gong Z, et al. Circular RNAs in Human Cancer. Molecular Cancer. 2017; 16: 25 .

31 Pienta KJ, McGregor N, Axelrod R, et al. Ecological Therapy for Cancer: Defining Tumors Using an Ecosystem Paradigm Suggests New Opportunities for Novel Cancer Treatments. Transl Oncol. 2008; 1: 158-64.

32 Chen F, Zhuang X, Lin L, et al. New horizons in tumor microenvironment biology: challenges and opportunities. BMC Med. 2015; 13: 45

33 Mroue R, Bissell MJ. Three-Dimensional Cultures of Mouse Mammary Epithelial Cells. In: Randell HS, Fulcher LM, eds. Epithelial Cell Culture Protocols: Second Edition. Humana Press: Totowa, NJ. 2013:221-50.

34 Karvonen HM, Lehtonen ST, Sormunen RT, et al. Lung cancer-associated myofibroblasts reveal distinctive ultrastructure and function. J Thorac Oncol. 2014; 9: 664-74

35 Karki S, Surolia R, Hock TD, et al. Wilms' tumor 1 (Wt1) regulates pleural mesothelial cell plasticity and transition into myofibroblasts in idiopathic pulmonary fibrosis. FASEB J. 2014; 28: 1122-31.

36 Shu H, Li HF. Prognostic effect of stromal myofibroblasts in lung adenocarcinoma. Neoplasma. 2012; 59: 658-61.

37 Grotendorst GR, Rahmanie H, Duncan MR. Combinatorial signaling pathways determine fibroblast proliferation and myofibroblast differentiation. FASEB J. 2004; 18: 469-79.
38 Orimo A, Gupta PB, Soroi DC, et al. Stromal fibroblasts present in invasive human breast carcinomas promote tumor growth and angiogenesis through elevated SDF-1/CXCL12 secretion. Cell. 2005; 121: 335-48.

39 Olumi AF, Grossfeld GD, Hayward SW, et al. Carcinoma-associated fibroblasts direct tumor progression of initiated human prostatic epithelium. Cancer Res. 1999; 59: 5002-11.

40 Busch S, Acar A, Magnusson Y, et al. TGF-beta receptor type-2 expression in cancer-associated fibroblasts regulates breast cancer cell growth and survival and is a prognostic marker in pre-menopausal breast cancer. Oncogene. 2015; 34: $27-38$

41 Kalluri R, Zeisberg M. Fibroblasts in cancer. Nat Rev Cancer. 2006; 6: 392-401.

42 Tanaka K, Miyata H, Sugimura K, et al. miR-27 is associated with chemoresistance in esophageal cancer through transformation of normal fibroblasts to cancer-associated fibroblasts. Carcinogenesis. 2015; 36: 894-903.

43 Min A, Zhu C, Peng S, et al. Downregulation of Microrna-148a in Cancer-Associated Fibroblasts from Oral Cancer Promotes Cancer Cell Migration and Invasion by Targeting Wnt10b. J Biochem Mol Toxicol. 2016; 30: 186-91.

44 Wiseman BS, Werb Z. Stromal effects on mammary gland development and breast cancer. Science. 2002; 296: 1046-9.

45 Xue X, Lu Z, Tang D, et al. Galectin-1 secreted by activated stellate cells in pancreatic ductal adenocarcinoma stroma promotes proliferation and invasion of pancreatic cancer cells: an in vitro study on the microenvironment of pancreatic ductal adenocarcinoma. Pancreas. 2011; 40: 832-9.

46 Saussez S, Decaestecker C, Cludts S, et al. Adhesion/growth-regulatory tissue lectin galectin-1 in relation to angiogenesis/lymphocyte infiltration and prognostic relevance of stromal up-regulation in laryngeal carcinomas. Anticancer Res. 2009; 29: 59-65.

47 van den Brule FA, Waltregny D, Castronovo V. Increased expression of galectin-1 in carcinoma-associated stroma predicts poor outcome in prostate carcinoma patients. J Pathol. 2001; 193: 80-7.

48 Jung EJ, Moon HG, Cho BI, et al. Galectin-1 expression in cancer-associated stromal cells correlates tumor invasiveness and tumor progression in breast cancer. Int J Cancer. 2007; 120: 2331-8.

$49 \mathrm{He}$ XJ, Tao HQ, Hu ZM, et al. Expression of galectin-1 in carcinoma-associated fibroblasts promotes gastric cancer cell invasion through upregulation of integrin beta1. Cancer Sci. 2014; 105: 1402-10.

50 Eberlein C, Rooney C, Ross SJ, et al. E-Cadherin and EpCAM expression by NSCLC tumour cells associate with normal fibroblast activation through a pathway initiated by integrin alphavbeta6 and maintained through TGFbeta signalling. Oncogene. 2015; 34: 704-16.

51 Jung Y, Kim JK, Shiozawa Y, et al. Recruitment of mesenchymal stem cells into prostate tumours promotes metastasis. Nat Commun. 2013; 4: 1795.

52 Fukui H, Zhang X, Sun C, et al. IL-22 produced by cancer-associated fibroblasts promotes gastric cancer cell invasion via STAT3 and ERK signaling. Br J Cancer. 2014; 111: 763-71.

53 Dowling CM, Herranz Ors C, Kiely PA. Using real-time impedance-based assays to monitor the effects of fibroblast-derived media on the adhesion, proliferation, migration and invasion of colon cancer cells. Biosci Rep. 2014; 34

54 Desmouliere A, Guyot C, Gabbiani G. The stroma reaction myofibroblast: a key player in the control of tumor cell behavior. Int J Dev Biol. 2004; 48: 509-17.

55 Huang J, Li Z, Ding $\mathrm{Z}$, et al. Different roles of myofibroblasts in the tumorigenesis of nonsmall cell lung cancer. Tumour Biol. 2015: 1-10.

56 Gout S, Huot J. Role of cancer microenvironment in metastasis: focus on colon cancer. Cancer Microenviron. 2008; 1: 69-83.

57 Hlatky L, Tsionou C, Hahnfeldt P, et al. Mammary Fibroblasts May Influence Breast Tumor Angiogenesis via Hypoxia-induced Vascular Endothelial Growth Factor Up-Regulation and Protein Expression. Cancer Res. 1994; 54: 6083-6.

58 Zucali JR, Dinarello CA, Oblon DJ, et al. Interleukin 1 stimulates fibroblasts to produce granulocyte-macrophage colony-stimulating activity and prostaglandin E2. J Clin Invest. 1986; 77: 1857-63.

59 Huleihel M, Douvdevani A, Segal S, et al. Regulation of interleukin 1 generation in immune-activated fibroblasts. Eur J Immunol. 1990; 20: 731-8.

$60 \mathrm{Yu}$ X, Graves DT. Fibroblasts, mononuclear phagocytes, and endothelial cells express monocyte chemoattractant protein-1 (MCP-1) in inflamed human gingiva. J Periodontol. 1995; 66: 80-8.

61 Ghatnekar A, Trojanowska M. GATA-6 is a novel transcriptional repressor of the human Tenascin-C gene expression in fibroblasts. Biochim Biophys Acta. 2008; 1779: 145-51.

62 Feig C, Jones JO, Kraman M, et al. Targeting CXCL12 from FAP-expressing carcinoma-associated fibroblasts synergizes with anti-PD-L1 immunotherapy in pancreatic cancer. Proc Natl Acad Sci U S A. 2013; 110: 20212-7.

63 Ohlund D, Elyada E, Tuveson D. Fibroblast heterogeneity in the cancer wound. J Exp Med. 2014; 211: 1503-23.

64 Berdiel-Acer M, Sanz-Pamplona R, Calon A, et al. Differences between CAFs and their paired NCF from adjacent colonic mucosa reveal functional heterogeneity of CAFs, providing prognostic information. Mol Oncol. 2014; 8: 1290-305.

65 Wendling O, Bornert JM, Chambon P, et al. Efficient temporally-controlled targeted mutagenesis in smooth muscle cells of the adult mouse. Genesis. 2009; 47: 14-8

66 Roberts EW, Deonarine A, Jones JO, et al. Depletion of stromal cells expressing fibroblast activation protein-alpha from skeletal muscle and bone marrow results in cachexia and anemia. J Exp Med. 2013; 210: 1137-51. 
67 Okada $\mathrm{H}$, Danoff TM, Kalluri $\mathrm{R}$ et al. Early role of $\mathrm{Fsp} 1$ in epithelial-mesenchymal transformation. Am J Physiol. 1997; 273: F563-74

68 Musumeci M, Coppola V, Addario A, et al. Control of tumor and microenvironment cross-talk by miR-15a and miR-16 in prostate cancer. Oncogene. 2011; 30: 4231-42.

69 Bronisz A, Godlewski J, Wallace JA, et al. Reprogramming of the tumour microenvironment by stromal PTEN-regulated miR-320. Nat Cell Biol. 2012; 14: $159-67$.

70 Aprelikova O, Palla J, Hibler B, et al. Silencing of miR-148a in cancer-associated fibroblasts results in WNT10B-mediated stimulation of tumor cell motility. Oncogene. 2013; 32: 3246-53.

71 Haubeiss S, Schmid JO, Murdter TE, et al. Dasatinib reverses cancer-associated fibroblasts (CAFs) from primary lung carcinomas to a phenotype comparable to that of normal fibroblasts. Mol Cancer. 2010; 9: 168

72 Yashiro M, Matsuoka T. Fibroblast growth factor receptor signaling as therapeutic targets in gastric cancer. World J Gastroenterol. 2016; 22: 2415-23.

73 Ding N, Yu RT, Subramaniam N, et al. A vitamin D receptor/SMAD genomic circuit gates hepatic fibrotic response. Cell. 2013; 153: 601-13.

74 Li M, Li M, Yin T, et al. Targeting of cancerassociated fibroblasts enhances the efficacy of cancer chemotherapy by regulating the tumor microenvironment. Mol Med Rep. 2016; 13: 2476-84.

75 Davis CD, Milner JA. Molecular targets for nutritional preemption of cancer. Curr Cancer Drug Targets. 2007; 7: 410-5.

76 Grivennikov SI, Greten FR, Karin M. Immunity, inflammation, and cancer. Cell. 2010; 140: 883-99.

77 Duan $\mathrm{Z}$, Zheng $\mathrm{H}, \mathrm{Xu} \mathrm{S}$, et al. Activation of the Ig Ialpha1 promoter by the transcription factor Ets-1 triggers Ig Ialpha1-Calpha1 germline transcription in epithelial cancer cells. Cell Mol Immunol. 2014; 11: 197-205.

$78 \mathrm{Hu} \mathrm{D}$, Duan Z, Li M, et al. Heterogeneity of aberrant immunoglobulin expression in cancer cells. Cell Mol Immunol. 2011; 8: 479-85.

$79 \mathrm{Hu} \mathrm{D}$, Zheng $\mathrm{H}$, Liu $\mathrm{H}$, et al. Immunoglobulin expression and its biological significance in cancer cells. Cell Mol Immunol. 2008; 5: 319-24.

$80 \mathrm{Li} \mathrm{M}$, Zheng H, Duan Z, et al. Promotion of cell proliferation and inhibition of ADCC by cancerous immunoglobulin expressed in cancer cell lines. Cell Mol Immunol. 2012; 9: 54-61.

81 Yang Y, Zhou H, Yang Y, et al. Lipopolysaccharide (LPS) regulates TLR4 signal transduction in nasopharynx epithelial cell line 5-8F via NFkappaB and MAPKs signaling pathways. Mol Immunol. 2007; 44: 984-92.

82 Zheng H, Li M, Ren W, et al. Expression and secretion of immunoglobulin alpha heavy chain with diverse VDJ recombinations by human epithelial cancer cells. Mol Immunol. 2007; 44: 2221-7.

83 Zhao R, Liu Y, Wang H, et al. BRD7 plays an anti-inflammatory role during early acute inflammation by inhibiting activation of the NF-small ka, CyrillicB signaling pathway. Cell Mol Immunol. 2017; DOI:10.1038/cmi.2016.31.

84 O'Sullivan T, Saddawi-Konefka R, Vermi W, et al. Cancer immunoediting by the innate immune system in the absence of adaptive immunity. J Exp Med. 2012; 209: 1869-82.

85 Dunn GP, Old LJ, Schreiber RD. The three Es of cancer immunoediting. Annu Rev Immunol. 2004; 22: 329-60.

86 Egeblad M, Nakasone ES, Werb Z. Tumors as organs: complex tissues that interface with the entire organism. Dev Cell. 2010; 18: 884-901.

87 Mantovani A. Molecular pathways linking inflammation and cancer. Curr Mol Med. 2010; 10: 369-73.

88 Qian BZ, Pollard JW. Macrophage diversity enhances tumor progression and metastasis. Cell. 2010; 141: 39-51.

89 Murdoch C, Muthana M, Coffelt SB, et al. The role of myeloid cells in the promotion of tumour angiogenesis. Nat Rev Cancer. 2008; 8: 618-31.

90 Ricciardi M, Zanotto M, Malpeli G, et al. Epithelial-to-mesenchymal transition (EMT) induced by inflammatory priming elicits mesenchymal stromal cell-like immune-modulatory properties in cancer cells. Br J Cancer. 2015; 112: 1067-75.

91 Bronkhorst IH, Ly LV, Jordanova ES, et al. Detection of M2-macrophages in uveal melanoma and relation with survival. Invest Ophthalmol Vis Sci. 2011; 52: $643-50$.

92 Ly LV, Baghat A, Versluis M, et al. In aged mice, outgrowth of intraocular melanoma depends on proangiogenic M2-type macrophages. J Immunol. 2010; 185 : 3481-8

93 Tao M, Liu L, Shen M, et al. Inflammatory stimuli promote growth and invasion of pancreatic cancer cells through NF-kappaB pathway dependent repression of PP2Ac. Cell Cycle. 2016; 15: 381-93.

94 Pathak BR, Breed AA, Apte S, et al. Cysteine-rich secretory protein 3 plays a role in prostate cancer cell invasion and affects expression of PSA and ANXA1. Mol Cell Biochem. 2016; 411: 11-21.

95 Jiang MH, Lim JE, Chi GF, et al. Substance P reduces apoptotic cell death possibly by modulating the immune response at the early stage after spinal cord injury. Neuroreport. 2013; 24: 846-51.

96 Konig A, Vilsmaier T, Rack B, et al. Determination of Interleukin-4, -5, -6, -8 and -13 in Serum of Patients with Breast Cancer Before Treatment and its Correlation to Circulating Tumor Cells. Anticancer Res. 2016; 36: 3123-30.

97 Savino W. Neuroendocrine control of T cell development in mammals: role of growth hormone in modulating thymocyte migration. Exp Physiol. 2007; 92: 813-7.

98 Razmkhah M, Jaberipour M, Erfani N, et al. Adipose derived stem cells (ASCs) isolated from breast cancer tissue express IL-4, IL-10 and TGF-beta1 and upregulate expression of regulatory molecules on $\mathrm{T}$ cells: do they protect breast cancer cells from the immune response? Cell Immunol. 2011; 266: $116-22$.

99 Caspar-Bauguil S, Cousin B, Andre M, et al. Weight-dependent changes of immune system in adipose tissue: importance of leptin. Exp Cell Res. 2006; 312: 2195-202.

100 Winer S, Winer DA. The adaptive immune system as a fundamental regulator of adipose tissue inflammation and insulin resistance. Immunol Cell Biol. 2012; 90: 755-62.

101 Wei N, Chen Z, Xue Z, et al. Polymorphism of VEGF gene in susceptibility to chronic immune-mediated inflammatory diseases: a meta-analysis. Rheumatol Int. 2015; 35: 1351-60.

102 Middleton E, Jr., Kandaswami C. Effects of flavonoids on immune and inflammatory cell functions. Biochem Pharmacol. 1992; 43: 1167-79.

103 Lolmede K, Campana L, Vezzoli M, et al. Inflammatory and alternatively activated human macrophages attract vessel-associated stem cells, relying on separate HMGB1- and MMP-9-dependent pathways. J Leukoc Biol. 2009; 85: $779-87$.

104 Zhang J, Silva T, Yarovinsky T, et al. VEGF blockade inhibits lymphocyte recruitment and ameliorates immune-mediated vascular remodeling. Circ Res. 2010; 107: 408-17.

105 Abbott RJ, Knott V, Roversi P, et al. Crystallization and preliminary X-ray diffraction analysis of three EGF domains of EMR2, a 7TM immune-system molecule. Acta Crystallogr D Biol Crystallogr. 2004; 60: 936-8.

106 Angell H, Galon J. From the immune contexture to the Immunoscore: the role of prognostic and predictive immune markers in cancer. Curr Opin Immunol. 2013; 25: 261-7

107 Manser AR, Uhrberg M. Age-related changes in natural killer cell repertoires: impact on NK cell function and immune surveillance. Cancer Immunol Immunother. 2016; 65: 417-26.

108 Butt AQ, Mills KH. Immunosuppressive networks and checkpoints controlling antitumor immunity and their blockade in the development of cancer immunotherapeutics and vaccines. Oncogene. 2014; 33: 4623-31.

109 Baeke F, Korf H, Overbergh L, et al. Human T lymphocytes are direct targets of 1,25-dihydroxyvitamin D3 in the immune system. J Steroid Biochem Mol Biol. 2010; 121: 221-7.

110 Baruch K, Rosenzweig N, Kertser A, et al. Breaking immune tolerance by targeting Foxp3(+) regulatory T cells mitigates Alzheimer's disease pathology. Nat Commun. 2015; 6: 7967.

111 Parker KH, Sinha P, Horn LA, et al. HMGB1 enhances immune suppression by facilitating the differentiation and suppressive activity of myeloid-derived suppressor cells. Cancer Res. 2014; 74: 5723-33.

112 Tiainen S, Tumelius R, Rilla K, et al. High numbers of macrophages, especially M2-like (CD163-positive), correlate with hyaluronan accumulation and poor outcome in breast cancer. Histopathology. 2015; 66: 873-83.

113 Dobrenis K, Gauthier LR, Barroca V, et al. Granulocyte colony-stimulating factor off-target effect on nerve outgrowth promotes prostate cancer development. Int J Cancer. 2015; 136: 982-8.

$114 \mathrm{Hu}$ P, Wang G, Shen M, et al. Intratumoral polymorphonuclear granulocyte is associated with poor prognosis in squamous esophageal cancer by promoting epithelial-mesenchymal transition. Future Oncol. 2015; 11: 771-83.

115 Yoshimura T, Imamichi T, Weiss JM, et al. Induction of Monocyte Chemoattractant Proteins in Macrophages via the Production of Granulocyte/Macrophage Colony-Stimulating Factor by Breast Cancer Cells. Front Immunol. 2016; $7: 2$.

116 Rizvi NA, Mazieres J, Planchard D, et al. Activity and safety of nivolumab, an anti-PD-1 immune checkpoint inhibitor, for patients with advanced, refractory squamous non-small-cell lung cancer (CheckMate 063): a phase 2, single-arm trial. Lancet Oncol. 2015; 16: 257-65.

117 Sun S, Fei X, Mao Y, et al. PD-1(+) immune cell infiltration inversely correlates with survival of operable breast cancer patients. Cancer Immunol Immunother. 2014; 63: 395-406.

118 Pardoll DM. The blockade of immune checkpoints in cancer immunotherapy. Nat Rev Cancer. 2012; 12: 252-64.

119 Hoechst B, Gamrekelashvili J, Manns MP, et al. Plasticity of human Th17 cells and iTregs is orchestrated by different subsets of myeloid cells. Blood. 2011; 117: 6532

120 Park JH, Han JH, Kang HY, et al. Expression of follicular helper T-cell markers in primary cutaneous T-cell lymphoma. Am J Dermatopathol. 2014; 36: 465-70.

121 Reiss KA, Forde PM, Brahmer JR. Harnessing the power of the immune system via blockade of PD-1 and PD-L1: a promising new anticancer strategy. Immunotherapy. 2014; 6: 459-75.

122 Byrne WL, Mills KH, Lederer JA, et al. Targeting regulatory T cells in cancer. Cancer Res. 2011; 71: 6915-20.

123 Sinha P, Clements VK, Bunt SK, et al. Cross-Talk between Myeloid-Derived Suppressor Cells and Macrophages Subverts Tumor Immunity toward a Type 2 Response. J Immunol. 2007; 179: 977-83.

124 Puig-Kröger A, Sierra-Filardi E, Domínguez-Soto A, et al. Folate Receptor $\beta$ Is Expressed by Tumor-Associated Macrophages and Constitutes a Marker for M2 Anti-inflammatory/Regulatory Macrophages. Cancer Res. 2009; 69: 9395.

125 Rasku MA, Clem AL, Telang S, et al. Transient T cell depletion causes regression of melanoma metastases. J Transl Med. 2008; 6: 12.

126 Kim Y, Pardoll D, Fu J, et al. Abstract 2495: STING agonists formulated into cancer vaccines (STINGVAX) can cure established tumor resistant to immune checkpoint blockade by activating NK cells. Cancer Res. 2015; 75: 2495. 
127 Coe D, Begom S, Addey C, et al. Depletion of regulatory T cells by anti-GITR $\mathrm{mAb}$ as a novel mechanism for cancer immunotherapy. Cancer Immunol Immunother. 2010; 59: 1367-77.

128 Pyonteck SM, Gadea BB, Wang HW, et al. Deficiency of the macrophage growth factor CSF-1 disrupts pancreatic neuroendocrine tumor development. Oncogene. 2012; 31: 1459-67.

129 Curiel TJ, Coukos G, Zou L, et al. Specific recruitment of regulatory T cells in ovarian carcinoma fosters immune privilege and predicts reduced survival. Nat Med. 2004; 10: 942-9.

130 Boesteanu AC, Katsikis PD. Memory T cells need CD28 costimulation to remember. Semin Immunol. 2009; 21: 69-77.

131 Parietti V, Monneaux F, Decossas M, et al. Function of CD4+,CD25+ Treg cells in MRL/lpr mice is compromised by intrinsic defects in antigen-presenting cells and effector T cells. Arthritis Rheum. 2008; 58: 1751-61.

132 Miwa S, Nishida H, Tanzawa Y, et al. TNF-alpha and tumor lysate promote the maturation of dendritic cells for immunotherapy for advanced malignant bone and soft tissue tumors. PLoS One. 2012; 7: e52926.

133 De Bock K, Cauwenberghs S, Carmeliet P. Vessel abnormalization: another hallmark of cancer? Molecular mechanisms and therapeutic implications. Curr Opin Genet Dev. 2011; 21: 73-9.

134 Hanahan D, Folkman J. Patterns and emerging mechanisms of the angiogenic switch during tumorigenesis. Cell. 1996; 86: 353-64.

135 Birbrair A, Zhang T, Wang ZM, et al. Type-2 pericytes participate in normal and tumoral angiogenesis. Am J Physiol Cell Physiol. 2014; 307: C25-38.

136 Hos D, Schlereth SL, Bock F, et al. Antilymphangiogenic therapy to promote transplant survival and to reduce cancer metastasis: what can we learn from the eye? Semin Cell Dev Biol. 2015; 38: 117-30.

137 Barankay T, Baumgartl $\mathrm{H}$, Lubbers DW, et al. Oxygen pressure in small lymphatics. Pflugers Arch. 1976; 366: 53-9.

138 Chovatiya R, Medzhitov R. Stress, inflammation, and defense of homeostasis. Mol Cell. 2014; 54: 281-8

139 Guillaumond F, Leca J, Olivares O, et al. Strengthened glycolysis under hypoxia supports tumor symbiosis and hexosamine biosynthesis in pancreatic adenocarcinoma. Proc Natl Acad Sci U S A. 2013; 110: 3919-24.

140 Koshikawa N, Iyozumi A, Gassmann M, et al. Constitutive upregulation of hypoxia-inducible factor-1[alpha] mRNA occurring in highly metastatic lung carcinoma cells leads to vascular endothelial growth factor overexpression upon hypoxic exposure. Oncogene. 2003; 22: 6717-24

141 Ito M, Minamiya $\mathrm{Y}$, Kawai $\mathrm{H}$, et al. Tumor-derived TGFbeta-1 induces dendritic cell apoptosis in the sentinel lymph node. J Immunol. 2006; 176: $5637-43$

142 Huang RR, Wen DR, Guo J, et al. Selective Modulation of Paracortical Dendritic Cells and T-Lymphocytes in Breast Cancer Sentinel Lymph Nodes. Breast J. 2000; 6: 225-32

143 Watanabe S, Deguchi K, Zheng R, et al. Tumor-induced CD11b+Gr-1+ myeloid cells suppress $\mathrm{T}$ cell sensitization in tumor-draining lymph nodes. J Immunol. 2008; 181: 3291-300.

144 Pereira ER, Jones D, Jung K, et al. The lymph node microenvironment and its role in the progression of metastatic cancer. Semin Cell Dev Biol. 2015; 38: 98-105.

145 Topalian SL, Drake CG, Pardoll DM. Targeting the PD-1/B7-H1(PD-L1) pathway to activate anti-tumor immunity. Curr Opin Immunol. 2012; 24: 207-12.

146 Padera TP, Meijer EF, Munn LL. The Lymphatic System in Disease Processes and Cancer Progression. Annu Rev Biomed Eng. 2016; 18: 125-58.

147 Nathanson SD, Shah R, Chitale DA, et al. Intraoperative clinical assessment and pressure measurements of sentinel lymph nodes in breast cancer. Ann Surg Oncol. 2014; 21: 81-5.

148 Shields JD, Borsetti M, Rigby H, et al. Lymphatic density and metastatic spread in human malignant melanoma. Br J Cancer. 2004; 90: 693-700.

149 Farnsworth RH, Karnezis T, Shayan R, et al. A role for bone morphogenetic protein-4 in lymph node vascular remodeling and primary tumor growth. Cancer Res. 2011; 71: 6547-57.

150 Dunn IF, Heese O, Black PM. Growth factors in glioma angiogenesis: FGFs, PDGF, EGF, and TGFs. J Neurooncol. 2000; 50: 121-37.

151 Christiaens V, Lijnen HR. Angiogenesis and development of adipose tissue. Mol Cell Endocrinol. 2010; 318: 2-9.

152 Kesavan P, McCabe F, Millar H, et al. Anti-CCL-2 / MCP-1 (monocyte chemoattractant protein-1) monoclonal antibodies effectively inhibit tumor angiogenesis and growth of human breast carcinoma. Cancer Res. 2005; 65: 254-.

153 Argaw AT, Zhang Y, Snyder BJ, et al. IL-1beta regulates blood-brain barrier permeability via reactivation of the hypoxia-angiogenesis program. J Immunol. 2006; 177: 5574-84

154 Banerji S, Ni J, Wang S-X, et al. LYVE-1, a New Homologue of the CD44 Glycoprotein, Is a Lymph-specific Receptor for Hyaluronan. J Cell Biol. 1999; 144: 789-801.

155 Ellis LM, Hicklin DJ. VEGF-targeted therapy: mechanisms of anti-tumour activity. Nat Rev Cancer. 2008; 8: 579-91.

156 Crawford Y, Ferrara N. VEGF inhibition: insights from preclinical and clinical studies. Cell Tissue Res. 2009; 335: 261-9.

157 Horowitz A, Simons M. Branching morphogenesis. Circ Res. 2008; 103: 784-95.

158 Jain RK. Normalization of tumor vasculature: an emerging concept in antiangiogenic therapy. Science. 2005; 307: 58-62.
159 Heath VL, Bicknell R. Anticancer strategies involving the vasculature. Nat Rev Clin Oncol. 2009; 6: 395-404

160 Fischer C, Mazzone M, Jonckx B, et al. FLT1 and its ligands VEGFB and PIGF: drug targets for anti-angiogenic therapy? Nat Rev Cancer. 2008; 8: 942-56.

161 Olofsson B, Pajusola K, Kaipainen A, et al. Vascular endothelial growth factor B, a novel growth factor for endothelial cells. Proc Natl Acad Sci U S A. 1996; 93: 2576-81.

162 Joukov V, Pajusola K, Kaipainen A, et al. A novel vascular endothelial growth factor, VEGF-C, is a ligand for the Flt4 (VEGFR-3) and KDR (VEGFR-2) receptor tyrosine kinases. EMBO J. 1996; 15: 290-8.

163 Yamada Y, Nezu J, Shimane M, et al. Molecular cloning of a novel vascular endothelial growth factor, VEGF-D. Genomics. 1997; 42: 483-8

164 Tang Y, Zhang D, Fallavollita L, et al. Vascular endothelial growth factor C expression and lymph node metastasis are regulated by the type I insulin-like growth factor receptor. Cancer Res. 2003; 63: 1166-71.

165 Gaengel K, Genove G, Armulik A, et al. Endothelial-mural cell signaling in vascular development and angiogenesis. Arterioscler Thromb Vasc Biol. 2009; 29: 630-8.

166 Bergers G, Song S, Meyer-Morse N, et al. Benefits of targeting both pericytes and endothelial cells in the tumor vasculature with kinase inhibitors. J Clin Invest. 2003; 111: 1287-95.

167 Nisancioglu MH, Betsholtz C, Genove G. The absence of pericytes does not increase the sensitivity of tumor vasculature to vascular endothelial growth factor-A blockade. Cancer Res. 2010; 70: 5109-15.

168 Tutunea-Fatan E, Majumder M, Xin X, et al. The role of CCL21/CCR7 chemokine axis in breast cancer-induced lymphangiogenesis. Mol Cancer. 2015; 14: 35.

169 Kazenwadel J, Secker GA, Liu YJ, et al. Loss-of-function germline GATA2 mutations in patients with MDS/AML or MonoMAC syndrome and primary lymphedema reveal a key role for GATA2 in the lymphatic vasculature. Blood. 2012; 119: 1283-91.

170 Ishii J, Yazawa T, Chiba T, et al. PROX1 Promotes Secretory Granule Formation in Medullary Thyroid Cancer Cells. Endocrinology. 2016; 157: 1289-98.

171 Cui L, Dang S, Qu J, et al. FOXC2 is up-regulated in pancreatic ductal adenocarcinoma and promotes the growth and migration of cancer cells. Tumour Biol. 2016; 37: 8579-85.

172 Rajala MW, Scherer PE. Minireview: The adipocyte--at the crossroads of energy homeostasis, inflammation, and atherosclerosis. Endocrinology. 2003; 144: 3765-73.

173 Gilbert CA, Slingerland JM. Cytokines, obesity, and cancer: new insights on mechanisms linking obesity to cancer risk and progression. Annu Rev Med. 2013; 64: 45-57.

174 Roberts DL, Dive C, Renehan AG. Biological mechanisms linking obesity and cancer risk: new perspectives. Annu Rev Med. 2010; 61: 301-16.

175 Naugler WE, Karin M. The wolf in sheep's clothing: the role of interleukin-6 in immunity, inflammation and cancer. Trends Mol Med. 2008; 14: 109-19.

176 Donohoe CL, O'Farrell NJ, Doyle SL, et al. The role of obesity in gastrointestinal cancer: evidence and opinion. Therap Adv Gastroenterol. 2014; 7: 38-50

177 Lago F, Gomez R, Gomez-Reino JJ, et al. Adipokines as novel modulators of lipid metabolism. Trends Biochem Sci. 2009; 34: 500-10.

178 Gilbert CA, Slingerland JM. Cytokines, Obesity, and Cancer: New Insights on Mechanisms Linking Obesity to Cancer Risk and Progression. Annu Rev Med. 2013; 64: 45-57.

179 Mohammadpour H, Pourfathollah AA, Nikougoftar Zarif M, et al. Irradiation enhances susceptibility of tumor cells to the antitumor effects of TNF-alpha activated adipose derived mesenchymal stem cells in breast cancer model. Sci Rep. 2016; 6: 28433.

180 Goodwin PJ, Stambolic V. Impact of the obesity epidemic on cancer. Annu Rev Med. 2015; 66: 281-96.

181 Key TJ, Appleby PN, Reeves GK, et al. Body Mass Index, Serum Sex Hormones, and Breast Cancer Risk in Postmenopausal Women. J Natl Cancer Inst. 2003; 95: 1218-26.

182 van Kruijsdijk RC, van der Wall E, Visseren FL. Obesity and cancer: the role of dysfunctional adipose tissue. Cancer Epidemiol Biomarkers Prev. 2009; 18: 2569-78

183 Joshi RK, Lee SA. Obesity related adipokines and colorectal cancer: a review and meta-analysis. Asian Pac J Cancer Prev. 2014; 15: 397-405.

184 Parekh N, Chandran U, Bandera EV. Obesity in cancer survival. Annu Rev Nutr. 2012; 32: 311-42.

185 Kolonin MG, Simmons PJ. Combinatorial stem cell mobilization. Nat Biotechnol. 2009; 27: 252-3.

186 Kolonin MG, Evans KW, Mani SA, et al. Alternative origins of stroma in normal organs and disease. Stem Cell Res. 2012; 8: 312-23.

187 Lee YH, Mottillo EP, Granneman JG. Adipose tissue plasticity from WAT to BAT and in between. Biochim Biophys Acta. 2014; 1842: 358-69.

188 Iwen KA, Priewe AC, Winnefeld $\mathrm{M}$, et al. Gluteal and abdominal subcutaneous adipose tissue depots as stroma cell source: gluteal cells display increased adipogenic and osteogenic differentiation potentials. Exp Dermatol. 2014; 23: 395-400.

189 Noel D, Caton D, Roche S, et al. Cell specific differences between human adipose-derived and mesenchymal-stromal cells despite similar differentiation potentials. Exp Cell Res. 2008; 314: 1575-84. 
190 Eterno V ZA, Pavesi L, Villani L, Zanini V, Petrolo G, et al. Adiposederived mesenchymal stem cells (ASCs) may favour breast cancer recurrence via HGF/c-Met signaling. Oncotarget. 2014; 5: 613-33.

191 Rowan BG, Gimble JM, Sheng M, et al. Human adipose tissue-derived stromal/stem cells promote migration and early metastasis of triple negative breast cancer xenografts. PLoS One. 2014; 9: e89595.

192 Gehmert S, Gehmert S, Prantl L, et al. Breast cancer cells attract the migration of adipose tissue-derived stem cells via the PDGF-BB/PDGFR-beta signaling pathway. Biochem Biophys Res Commun. 2010; 398: 601-5.

193 Amos PJ, Shang H, Bailey AM, et al. IFATS collection: The role of human adipose-derived stromal cells in inflammatory microvascular remodeling and evidence of a perivascular phenotype. Stem Cells. 2008; 26: 2682-90.

194 Jotzu C, Alt E, Welte G, et al. Adipose tissue derived stem cells differentiate into carcinoma-associated fibroblast-like cells under the influence of tumor derived factors. Cell Oncol (Dordr). 2011; 34: 55-67.

195 Cho JA, Park H, Lim EH, et al. Exosomes from ovarian cancer cells induce adipose tissue-derived mesenchymal stem cells to acquire the physical and functional characteristics of tumor-supporting myofibroblasts. Gynecol Oncol. 2011; 123: 379-86.

196 Jeon ES, Heo SC, Lee IH, et al. Ovarian cancer-derived lysophosphatidic acid stimulates secretion of VEGF and stromal cell-derived factor-1 alpha from human mesenchymal stem cells. Exp Mol Med. 2010; 42: 280-93.

197 Do EK, Kim YM, Heo SC, et al. Lysophosphatidic acid-induced ADAM12 expression mediates human adipose tissue-derived mesenchymal stem cell-stimulated tumor growth. Int J Biochem Cell Biol. 2012; 44: 2069-76.

198 Park YM, Yoo SH, Kim SH. Adipose-derived stem cells induced EMT-like changes in H358 lung cancer cells. Anticancer Res. 2013; 33: 4421-30.

199 Zimmerlin L, Donnenberg AD, Rubin JP, et al. Regenerative therapy and cancer: in vitro and in vivo studies of the interaction between adipose-derived stem cells and breast cancer cells from clinical isolates. Tissue Eng Part A. 2011; 17: 93-106.

200 Devarajan E, Song YH, Krishnappa S, et al. Epithelial-mesenchymal transition in breast cancer lines is mediated through PDGF-D released by tissue-resident stem cells. Int J Cancer. 2012; 131: 1023-31.

201 Pinilla S, Alt E, Abdul Khalek FJ, et al. Tissue resident stem cells produce CCL5 under the influence of cancer cells and thereby promote breast cancer cell invasion. Cancer Lett. 2009; 284: 80-5.

202 Lee Y, Jung WH, Koo JS. Adipocytes can induce epithelial-mesenchymal transition in breast cancer cells. Breast Cancer Res Treat. 2015; 153: 323-35.

203 Quarto N, Senarath-Yapa K, Renda A, et al. TWIST1 silencing enhances in vitro and in vivo osteogenic differentiation of human adipose-derived stem cells by triggering activation of BMP-ERK/FGF signaling and TAZ upregulation. Stem Cells. 2015; 33: 833-47.

204 Goodwin PJ. Obesity and endocrine therapy: host factors and breast cancer outcome. Breast. 2013; 22 Suppl 2: S44-7.

205 Maccio A, Madeddu C, Mantovani G. Adipose tissue as target organ in the treatment of hormone-dependent breast cancer: new therapeutic perspectives. Obes Rev. 2009; 10: 660-70

206 Yin N, Wang D, Zhang H, et al. Molecular mechanisms involved in the growth stimulation of breast cancer cells by leptin. Cancer Res. 2004; 64: 5870-5.

207 Delort L, Rossary A, Farges MC, et al. Leptin, adipocytes and breast cancer: Focus on inflammation and anti-tumor immunity. Life Sci. 2015; 140: 37-48.

208 Lopez R, Arumugam A, Joseph R, et al. Hyperglycemia enhances the proliferation of non-tumorigenic and malignant mammary epithelial cells through increased leptin/IGF1R signaling and activation of AKT/mTOR. PLoS One. 2013; 8: e79708.

209 Jung JS, Jee MK, Cho HT, et al. MBD6 is a direct target of Oct4 and controls the stemness and differentiation of adipose tissue-derived stem cells. Cell Mol Life Sci. 2013; 70: 711-28.

210 Wang X, Simpson ER, Brown KA. Aromatase overexpression in dysfunctional adipose tissue links obesity to postmenopausal breast cancer. J Steroid Biochem Mol Biol. 2015; 153: 35-44.

211 Ioannides SJ, Barlow PL, Elwood JM, et al. Effect of obesity on aromatase inhibitor efficacy in postmenopausal, hormone receptor-positive breast cancer: a systematic review. Breast Cancer Res Treat. 2014; 147: 237-48.

212 Montuenga LM, Guembe L, Burrell MA, et al. The diffuse endocrine system: from embryogenesis to carcinogenesis. Prog Histochem Cytochem. 2003; 38: 155-272.

213 Gunawardene AR, Corfe BM, Staton CA. Classification and functions of enteroendocrine cells of the lower gastrointestinal tract. Int J Exp Pathol. 2011; 92: $219-31$.

214 di Sant'Agnese PA. Neuroendocrine differentiation in carcinoma of the prostate. Diagnostic, prognostic, and therapeutic implications. Cancer. 1992; 70: 254-68.

215 Linnoila RI. Functional facets of the pulmonary neuroendocrine system. Lab Invest. 2006; 86: 425-44.

216 Ayala GE, Dai H, Powell M, et al. Cancer-related axonogenesis and neurogenesis in prostate cancer. Clin Cancer Res. 2008; 14: 7593-603.

217 Lala PK, Parhar RS, Singh P. Indomethacin therapy abrogates the prostaglandin-mediated suppression of natural killer activity in tumor-bearing mice and prevents tumor metastasis. Cell Immunol. 1986; 99: 108-18.

218 Levite M. Nerve-driven immunity. The direct effects of neurotransmitters on T-cell function. Ann N Y Acad Sci. 2000; 917: 307-21.
219 Lang K, Drell TL, Niggemann B, et al. Neurotransmitters regulate the migration and cytotoxicity in natural killer cells. Immunol Lett. 2003; 90: 165-72.

220 Delgado AV, McManus AT, Chambers JP. Production of tumor necrosis factor-alpha, interleukin 1-beta, interleukin 2, and interleukin 6 by rat leukocyte subpopulations after exposure to substance P. Neuropeptides. 2003; 37: 355-61.

221 Lang K, Entschladen F, Weidt C, et al. Tumor immune escape mechanisms: impact of the neuroendocrine system. Cancer Immunol Immunother. 2006; 55 : $749-60$.

222 Epstein JI, Amin MB, Beltran H, et al. Proposed morphologic classification of prostate cancer with neuroendocrine differentiation. Am J Surg Pathol. 2014; 38: 756-67.

223 Tanaka M, Suzuki Y, Takaoka K, et al. Progression of prostate cancer to neuroendocrine cell tumor. Int J Urol. 2001; 8: 431-6; discussion 7.

224 Jin RJ, Wang Y, Masumori N, et al. NE-10 neuroendocrine cancer promotes the LNCaP xenograft growth in castrated mice. Cancer Res. 2004; 64: 5489-95.

225 Gout S, Huot J. Role of Cancer Microenvironment in Metastasis: Focus on Colon Cancer. Cancer Microenviron. 2008; 1: 69-83.

226 Kaltsas GA, Besser GM, Grossman AB. The diagnosis and medical management of advanced neuroendocrine tumors. Endocr Rev. 2004; 25: 458-511.

227 Jiang N, Zhu S, Chen J, et al. A-methylacyl-CoA racemase (AMACR) and prostate-cancer risk: a meta-analysis of 4,385 participants. PLoS One. 2013; 8: e74386.

228 Olar A, He D, Florentin D, et al. Biologic correlates and significance of axonogenesis in prostate cancer. Hum Pathol. 2014; 45: 1358-64.

229 Vlachostergios PJ, Papandreou CN. Targeting neuroendocrine prostate cancer: molecular and clinical perspectives. Front Oncol. 2015; 5: 6.

230 Leiblich A, Cross SS, Catto JW, et al. Human prostate cancer cells express neuroendocrine cell markers PGP 9.5 and chromogranin A. Prostate. 2007; 67: $1761-9$

231 Grigore AD, Ben-Jacob E, Farach-Carson MC. Prostate cancer and neuroendocrine differentiation: more neuronal, less endocrine? Front Oncol. 2015; 5 : 37.

232 Tsao KC, Wu JT. Development of an ELISA for the detection of serum chromogranin $\mathrm{A}(\mathrm{CgA})$ in prostate and non-neuroendocrine carcinomas. Clin Chim Acta. 2001; 313: 21-9.

233 Von Dorsche HH, Fält K, Hahn H-J, et al. Neuron-specific enolase (NSE) as a neuroendocrine cell marker in the human fetal pancreas. Acta Histochemica. 1989; $85: 227-8$

234 Modlin IM, Bodei L, Kidd M. Neuroendocrine tumor biomarkers: From monoanalytes to transcripts and algorithms. Best Pract Res Clin Endocrinol Metab. 2016; 30: 59-77.

235 Berkovic MC, Jokic M, Marout J, et al. IL-2 -330 T/G SNP and serum values-potential new tumor markers in neuroendocrine tumors of the gastrointestinal tract and pancreas (GEP-NETs). J Mol Med (Berl). 2010; 88: 423-9.

236 Chen G, Jaskula-Sztul R, Harrison A, et al. KE108-conjugated unimolecular micelles loaded with a novel HDAC inhibitor thailandepsin-A for targeted neuroendocrine cancer therapy. Biomaterials. 2016; 97: 22-33.

237 Saunders LR, Bankovich AJ, Anderson WC, et al. A DLL3-targeted antibody-drug conjugate eradicates high-grade pulmonary neuroendocrine tumor-initiating cells in vivo. Sci Transl Med. 2015; 7: 302ra136.

238 Nagashio $R$, Sato $\mathrm{Y}$, Matsumoto $\mathrm{T}$, et al. Significant high expression of cytokeratins $7,8,18,19$ in pulmonary large cell neuroendocrine carcinomas, compared to small cell lung carcinomas. Pathol Int. 2010; 60: 71-7.

239 Sorhaug S, Steinshamn S, Haaverstad R, et al. Expression of neuroendocrine markers in non-small cell lung cancer. APMIS. 2007; 115: 152-63.

240 Sun RF, Liu ZG, Ma G, et al. Prognostic value of neuroendocrine markers for predicting survival in patients with small cell lung cancer. Int J Clin Exp Pathol. 2016; 9: 5970-9.

241 van der Zwan WA, Bodei L, Mueller-Brand J, et al. GEPNETs update: Radionuclide therapy in neuroendocrine tumors. Eur J Endocrinol. 2015; 172: R1-8.

242 Di Florio A, Sancho V, Moreno P, et al. Gastrointestinal hormones stimulate growth of Foregut Neuroendocrine Tumors by transactivating the EGF receptor. Biochim Biophys Acta. 2013; 1833: 573-82.

243 Kashyap R, Hofman MS, Michael M, et al. Favourable outcomes of (177)Lu-octreotate peptide receptor chemoradionuclide therapy in patients with FDG-avid neuroendocrine tumours. Eur J Nucl Med Mol Imaging. 2015; 42: $176-85$

244 Carver BS. Defining and Targeting the Oncogenic Drivers of Neuroendocrine Prostate Cancer. Cancer Cell. 2016; 29: 431-2.

245 Monboisse JC, Oudart JB, Ramont L, et al. Matrikines from basement membrane collagens: a new anti-cancer strategy. Biochim Biophys Acta. 2014; 1840: 2589-98.

246 Chelberg MK, Tsilibary EC, Hauser AR, et al. Type IV collagen-mediated melanoma cell adhesion and migration: involvement of multiple, distinct domains of the collagen molecule. Cancer Res. 1989; 49: 4796-802.

247 Brown E, McKee T, diTomaso E, et al. Dynamic imaging of collagen and its modulation in tumors in vivo using second-harmonic generation. Nat Med. 2003; 9: 796-800. 
248 Schminke B, Frese J, Bode C, et al. Laminins and Nidogens in the Pericellular Matrix of Chondrocytes: Their Role in Osteoarthritis and Chondrogenic Differentiation. Am J Pathol. 2016; 186: 410-8.

249 Yamada KM, Olden K. Fibronectins[mdash]adhesive glycoproteins of cell surface and blood. Nature. 1978; 275: 179-84.

250 Kim LB, Shkurupy VA, Putyatina AN. Dynamic Structure of Proteoglycans/Glycosaminoglycans in the Lungs of Mice with Chronic Granulomatous Inflammation. Bull Exp Biol Med. 2016; 160: 435-8.

251 Dahl LB, Dahl IM, Engstrom-Laurent A, et al. Concentration and molecular weight of sodium hyaluronate in synovial fluid from patients with rheumatoid arthritis and other arthropathies. Ann Rheum Dis. 1985; 44: 817-22.

252 Goldberg VM, Buckwalter JA. Hyaluronans in the treatment of osteoarthritis of the knee: evidence for disease-modifying activity. Osteoarthritis Cartilage. 2005; 13: 216-24

253 Zhu J, Liang L, Jiao Y, et al. Enhanced invasion of metastatic cancer cells via extracellular matrix interface. PLoS One. 2015; 10: e0118058.

$254 \mathrm{Yu}$ J, Liu Y, Guo C, et al. Upregulated long non-coding RNA LINC00152 expression is associated with progression and poor prognosis of tongue squamous cell carcinoma. J Cancer. 2017; 8(4):523-30.

255 Zhou YJ, Liao QJ, Li XY, et al. HYOU1, Regulated by LPLUNC1, Is Up-Regulated in Nasopharyngeal Carcinoma and Associated with Poor Prognosis. J Cancer. 2016; 7: 367-76.

256 Zeng Z, Bo H, Gong Z, et al. AFAP1-AS1, a long noncoding RNA upregulated in lung cancer and promotes invasion and metastasis. Tumour Biol. 2016; 37: 729-37.

257 Xiao K, Yu Z, Li X, et al. Genome-wide Analysis of Epstein-Barr Virus (EBV) Integration and Strain in C666-1 and Raji Cells. J Cancer. 2016; 7: 214-24.

258 Song Y, Li X, Zeng Z, et al. Epstein-Barr virus encoded miR-BART11 promotes inflammation-induced carcinogenesis by targeting FOXP1. Oncotarget. 2016; 7: 36783-99.

259 Lian Y, Li XY, Tang YY, et al. Long Non-coding RNAs Function as Competing Endogenous RNAs to Regulate Cancer Progression. Prog Biochem Biophys. 2016; 43: 219-25.

$260 \mathrm{He}$ B, Li W, Wu Y, et al. Epstein-Barr virus-encoded miR-BART6-3p inhibits cancer cell metastasis and invasion by targeting long non-coding RNA LOC553103. Cell Death Dis. 2016; 7: e2353.

261 Gong $Z$, Yang $Q$, Zeng $Z$, et al. An integrative transcriptomic analysis reveals p53 regulated miRNA, mRNA, and lncRNA networks in nasopharyngeal carcinoma. Tumour Biol. 2016; 37: 3683-95.

262 Yan $\mathrm{O}$, Zeng $Z$, Gong $Z$, et al. EBV-miR-BART10-3p facilitates epithelial-mesenchymal transition and promotes metastasis of nasopharyngeal carcinoma by targeting BTRC. Oncotarget. 2015; 6: 41766-82.

263 Howlett AR, Bissell MJ. The influence of tissue microenvironment (stroma and extracellular matrix) on the development and function of mammary epithelium. Epithelial Cell Biol. 1993; 2: 79-89.

264 Liao Q, Zeng Z, Guo X, et al. LPLUNC1 suppresses IL-6-induced nasopharyngeal carcinoma cell proliferation via inhibiting the Stat3 activation. Oncogene. 2014; 33: 2098-109.

265 Gong Z, Zhang S, Zeng Z, et al. LOC401317, a p53-regulated long non-coding RNA, inhibits cell proliferation and induces apoptosis in the nasopharyngeal carcinoma cell line HNE2. PLoS One. 2014; 9: e110674.

266 Yang Y, Liao Q, Wei F, et al. LPLUNC1 inhibits nasopharyngeal carcinoma cell growth via down-regulation of the MAP kinase and cyclin D1/E2F pathways. PLoS One. 2013; 8: e62869.

267 Gattazzo F, Urciuolo A, Bonaldo P. Extracellular matrix: a dynamic microenvironment for stem cell niche. Biochim Biophys Acta. 2014; 1840: 2506-19.

268 Popovic ZV, Sandhoff R, Sijmonsma TP, et al. Sulfated Glycosphingolipid as Mediator of Phagocytosis: SM4s Enhances Apoptotic Cell Clearance and Modulates Macrophage Activity. J Immunol. 2007; 179: 6770-82.

269 O'Connell J, O'Sullivan GC, Collins JK, et al. The Fas counterattack: Fas-mediated T cell killing by colon cancer cells expressing Fas ligand. J Exp Med. 1996; 184: 1075-82.

270 Gong ZJ, Huang HB, Xu K, et al. Advances in microRNAs and TP53 Gene Regulatory Network. Prog Biochem Biophys. 2012; 39: 1133-44.

271 Huang HB, Liang F, Xiong W, et al. Bioinformatics Accelerates Drug Repositioning. Prog Biochem Biophys. 2012; 39: 35-44

272 Huang HB, Deng M, Zheng Y, et al. Innate immune protein lactotransferrin prevents initiation and arrests progression of nasopharyngeal carcinoma. Prog Biochem Biophys. 2013; 40: 319-24.

273 Liang F, Xu K, Gong ZJ, et al. ChIP-seq: a New Technique for Genome-wide Profiling of Protein-DNA Interaction. Prog Biochem Biophys. 2013; 40: 216-27.

274 Tang K, Wei F, Bo H, et al. Cloning and Functional Characterization of a Novel Long Non-coding RNA Gene Associated With Hepatocellular Carcinoma. Prog Biochem Biophys. 2014; 41: 153-62.

$275 \mathrm{Yu}$ ZY, Song YL, Gong ZJ, et al. The Mechanism and Tumorigenesis of Oncogenic DNA Virus Integration. Prog Biochem Biophys. 2014; 41: 324-31.

$276 \mathrm{Li}$ YW, Wang YM, Zhang XY, et al. Progress of Long Noncoding RNA HOTAIR in Human Cancer. Prog Biochem Biophys. 2015; 42: 228-35.

277 Tu CF, Qi P, Li XY, et al. Tumor Heterogeneity: The Challenge of Precision Medicine. Prog Biochem Biophys. 2015; 42: 881-90. 